Pig Housing and the Environment

Occasional Publication No. 11-British Society of Animal Production 1987

edited by A. T. Smith and T. L. J. Lawrence

\title{
QUANTIFYING ODOURS FROM SPREADING PIG SLURRY ON LAND
}

\author{
B. F. PAIN and Y. J. REES \\ AFRC Institute of Grassland and Animal Production Research, Hurley, Maidenhead SL6 SLR \\ and \\ V. C. NEILSEN and C. R. CLARKSON \\ MAFF/ADAS Farm Waste Unit, 79-81 Basingstoke Road, Reading RG2 OEF
}

\section{INTRODUCTION}

$\mathbf{J}$ ustifiable complaints from the public about odours from livestock farms have increased from 60 to 70 per year between 1960 and 1970 to the current level of about 2500 per year. The problem is most severe from pig enterprises and about $45 \%$ of all complaints are associated with spreading slurry on land.

The objective of the present study was to develop and to assess a quantitative technique for measuring the rate of odour emission from slurry applied to land. Such a technique is a pre-requisite to both the development and assessment of slurry management strategies, machinery and treatment processes used for odour control.

\section{METHODS}

A system of small wind tunnels (Lockyer, 1984) together with dynamic dilution olfactometry (Bedborough and Trott, 1979) was used to collect and to measure the strength of odours emitted following the application of pig slurry to grassland. The design of the tunnels ensured that natural sward conditions were influenced as little as possible and allowed air speed through the tunnels to be controlled over the range normally encountered in the field. Each tunnel consisted of a transparent plastic canopy $(2.0 \times 0.5 \mathrm{~m})$ coupled to a steel duct of circular cross section housing a variablespeed axial-flow fan. Samples of the air drawn through the tunnels was collected in 40 to 501 capacity polyvinyl flouride (Tedlar) bags and assessed by olfactometry as soon as possible after collection. The olfactometer operated on the principle of diluting a sample of odorous air with different volumes of clean air to establish the number of dilutions required for an odour to be just perceived by $50 \%$ of members of a panel (the $\mathrm{DF}_{50}$ ). This equipment was hired from and operated by the Warren Spring Laboratory, Stevenage.

The slurries used in the experiments were obtained from a pig fattening house. Total solids, total volatile fatty acids and total nitrogen concentrations were in the range 1 to $2 \%, 5$ to $8 \mathrm{~g} / 1$ and 0.25 to $0.40 \%$ respectively. For experiments, slurry was spread evenly over $2.0 \times$ $0.5 \mathrm{~m}$ areas of grassland and a tunnel immediately placed into position. Odour units were calculated from the $\mathrm{DF}_{50}$ and the volume of air drawn through the tunnel and rate of odour emission expressed as odour units per $\mathrm{m}^{2}$ per $\mathrm{h}$.

\section{RESULTS}

The maximum $\mathrm{DF}_{50}$ recorded for freshly applied pig slurry was 800 but values were generally much lower. This maximum value was equivalent to a rate of odour emission of $60 \times 10^{-4} \mathrm{~m}^{2} / \mathrm{h}$. The $\mathrm{DF}_{50}$ values for pig slurry were low compared with the values of between 1200 and 4000000 reported for industrial odour emissions.

The highest values were normally recorded within $1 \mathrm{~h}$ of applying slurry but these rapidly declined to much lower levels within $4 \mathrm{~h}$. The $\mathrm{DF}_{50}$ values normally fell below the level detectable by the olfactometer within 24 to $36 \mathrm{~h}$ of slurry application.

Table 1 gives typical results obtained from applying pig slurry at $20 \mathrm{1} / \mathrm{m}^{2}$ with an air speed through the tunnel of $1 \mathrm{~m} / \mathrm{s}$. 


\section{TABLE 1}

$D F_{50}$ and rate of odour emission from pig slurry applied to grassland at $201 / \mathrm{m}^{2}$ during late winter: mean values from three Tedlar bags

\begin{tabular}{|c|c|c|c|c|c|}
\hline \multirow{2}{*}{\multicolumn{2}{|c|}{$\begin{array}{l}\text { Time after } \\
\text { slurry } \\
\text { application } \\
\text { (h) }\end{array}$}} & \multicolumn{2}{|c|}{$\mathrm{DF}_{50}$} & \multicolumn{2}{|c|}{$\begin{array}{l}\text { Rate of odour } \\
\text { emission } \\
\text { (odour units } \\
\text { per } \mathrm{m}^{2} \text { per } \mathrm{h} \\
\times 10^{-4} \text { ) }\end{array}$} \\
\hline & & Mean & s.e. & Mean & s.e. \\
\hline 1.0 & & 760 & 78.2 & $52 \cdot 0$ & 8.80 \\
\hline $2 \cdot 5$ & & 233 & $16 \cdot 7$ & $15 \cdot 0$ & 1.03 \\
\hline 4.5 & & 107 & 6.7 & $7 \cdot 5$ & 1.81 \\
\hline $23 \cdot 0$ & & 45 & $2 \cdot 9$ & 3.5 & $0 \cdot 11$ \\
\hline
\end{tabular}

Increasing rate of application increased the rate of odour emission although the differences were small. For example, accumulative odour emission $24 \mathrm{~h}$ after application was 120 and 160 odour units per $\mathrm{m}^{2}$ per $\mathrm{h} X$ $10^{-4}$ for 5 and 201 slurry per $\mathrm{m}^{2}$ respectively. Odour emission was greater at an airspeed of $3 \mathrm{~m} / \mathrm{s}$ than at $1 \mathrm{~m} / \mathrm{s}$, due primarly to the larger volume of air drawn through the tunnel at the higher airspeed than to a significantly greater $\mathrm{DF}_{50}$. Although the experiments were carried out under a narrow range of ambient temperatures during late winter, there was evidence for a strong positive correlation $(r=0.94)$ between rate of odour emission and air temperature.

\section{CONCLUSIONS}

(1) The strength of odours emitted following application of pig siurry to land are generally much lower than those reported from industrial sources.

(2) The rate of odour emission (odour units per $\mathrm{m}^{2}$ per h) is greatest immediately after slurry application but declines to a much lower level within 4 to $5 \mathrm{~h}$.

(3) The rate of odour emission appears to be influenced by rate of slurry application, airspeed and ambient temperature.

\section{REFERENCES}

Bedborough, D. R. and Trott, P. E. 1979. The sensory measurement of odours by dynamic dilution. Report, Warren Spring Laboratory, Stevenage, No. LR299.

LOCK YER, D. R. 1984. A system for the measurement in the field of losses of ammonia through volatilization. Journal of the Science of Food and Agriculture 35: 837-848. 